\title{
Swearing: A "Bad" Part of Language; A Good Part of Language Learning
}

\section{Robin-Eliece Mercury}

\begin{abstract}
This article proposes that class treatment of taboo language can be beneficial for language learning students. This is not to say that all groups of ESL learners would benefit, nor that instructors should teach their students how to swear in English. However, I suggest that learners need to understand what constitutes "obscene" language in North American contexts, why native speakers choose to use it, and what it signifies sociolinguistically. Arguments are made as to why an ESL classroom may be one of the better places (i.e., a more responsible, mature environment) where $L 2$ speakers can receive explanations about the usage and paradoxes involved in swearing. The author's experience related to the use of taboo language by L2 speakers in a non-English speaking environment is described. In addition, some nonlinguistic variables relevant to cursing are also discussed. As a means to open this topic for discussion, this article suggests that there is, in terms of sociolinguistics, study value in the nature and use of obscene language for language learners.
\end{abstract}

In this article I discuss why obscene language needs far more attention from language teachers than it has received until now. Specifically, I believe adult language learners (i.e., 18 years or older) in ESL/EFL courses designed to teach students how to communicate in English in everyday, common, or general situations could benefit from lessons that focus on the nature and the use of taboo language. I do not mean ESL learners should learn how to swear; rather, learners need to understand what constitutes obscene language in North American contexts, why native speakers choose to use it, and what it signifies sociolinguistically. Perhaps because obscenities are often proscribed, teachers shy away from them and virtually fail to consider their sociolinguistic importance. De Klerk (1991) observes "studies on linguistic taboo have tended to be neglected for obvious reasons", but she argues "how revealing use of such taboos can be of the social variables by which speakers are affected" (p. 164). Of course, it can be argued that a speaker's use of obscene language is superfluous. Lexically, non-taboo words can be substituted for taboo expressions (i.e., making love for fucking). A speaker's intended meaning can be expressed in a nonoffensive way. This is a reasonable argument, in terms of denotation; yet connotatively, non-taboo expressions do not carry the same significance as taboo expressions. Would listeners evaluate "clean" speech in the same way they would obscene speech? Is 
there a difference in meaning between This shirt is made of poor quality material and This shirt is made of shitty material? Much is lost in the translation, and most of what is lost is largely related to the connotative meanings in the taboo words speakers choose to use.

The connotations of obscene words are, like those of most words, products of the sociolinguistic rules that help to shape a speech event and that influence the verbal behavior between a speaker and a listener (Foote \& Woodward, 1973; Jay, 1981, 1992; de Klerk, 1991; Sagarin, 1968; Selnow, 1985).

Therefore, the connotative interpretations that are possible for words such as asshole, cocksucker, bastard, and so on reveal much about the sociocultural conditions that surround their use. In essence, taboo language could prove to be pedagogically useful. There is much for ESL students to learn about the social forces behind swearing in English and among English speakers. It is useful still if students only learn to understand, for practical reasons, why a speaker would choose to use obscenities and when she or he would choose not to.

All types of taboo language: obscenities, vulgarisms, curses, expletives, profanities, and so forth are a part of most, if not all, languages (Foote \& Woodward, 1973; Sagarin, 1968). They certainly have been a pervasive part of conversational English in the latter half of the 20th century in North America (Arango, 1989; Black, Stratton, Nichols, \& Chavez, 1985). Although American and Canadian English speakers are not generally indiscriminate users or approvers of taboo language (Jay, 1992) — no society is-it is nonetheless an important aspect of contemporary communication (Black et al., 1985; Hall, Nagy, \& Linn, 1984). Because it is widely heard among native speakers, mature language learners could benefit from classroom discussions devoted to examining the use and significance of obscene language, at least in broadly based contexts.

In light of the above discussion, this article explores the sociolinguistic importance of obscene language in North America (but primarily in United States society) and the ways in which English language learners may better understand the nonlinguistic forces that influence its use. However, first I would like to explain briefly a few of the most basic types of taboo words or expressions that North American speakers use.

\section{Definition of Terms}

Functional distinctions are made among the kinds of obscene language one can usually use or hear. These distinctions are mainly based on the function the words or expressions serve. The main focus here is the social complexities involved in using obscenities; pragmatic distinctions are more relevant to the arguments made in this article than etymological or grammatical ones. Jay's (1992) work is the most current research on dirty language 
(an expression he prefers to use), and he provides clear, useful definitions for the many terms used to label offensive language. Jay points out that pragmatic distinctions can be made because each "curse event" is "coherent in that it fulfills specific types of needs and intentions of the speaker and listener" (p. 2).

Cursing. These expressions act like verbal assaults where a speaker targets a specific individual, group, or thing and clearly wishes harm, pain, or other evil consequences on him, her, or it. Generally, curses are proscribed by the churches and society in general for this very reason, so curses such as eat shit and die! are considered to be powerfully threatening utterances.

Profanity. Jay (1992) describes these expressions as using "religious terminology in a profane, secular or indifferent manner" (p. 3). There is no intention on the speaker's part to denigrate God or anything associated with religion. Rather, the speaker may be expressing his or her emotional reaction to a certain stimulus. Examples in this case would be Jesus Christ! let's go; we're late as it is or Good God! he's ugly!

Blasphemy. Blasphemous expressions, on the other hand, are a deliberate use of religious terminology to denigrate God, religious icons, and religious institutions. Blasphemy can provoke strong reactions where speakers labelled as blasphemers can be ostracized or mortally threatened. Recall that author Salman Rushdie continues to remain in hiding from potential assassins because Islamic clergy labelled him a blasphemer.

Taboo or obscenity. All obscene language is taboo language because these expressions are restricted in some way for their use in public. These restrictions exist explicitly (e.g., television network censors who govern language on television) or implicitly (parents who use euphemisms to describe sexual body parts or body processes when talking to their children, Arango, 1989). As such, then, taboo words are not supposed to be spoken anywhere, anytime. Of course, though, everyone hears so many of them in public places (i.e., on the streets) that it is difficult to understand the degree to which they are taboo, but for the sake of illustrating my point, even though words such as fuck, damn, and son-of-a-bitch are frequently used, they are socially frowned on and thus taboo.

Vulgarisms. Generally, these are expressions that are crude, raw, and from off the streets. Vulgar language is used to debase or devalue the thing or individual referred to or described. I have to take a crap and Wow, look at her tits! are just two colorful yet vulgar utterances that would in some contexts be regarded as insensitive, distasteful, and offensive (Carpenter, 1988).

Expletives. These are interjections that are clearly emotionally charged (i.e., Shit! Balls!). Not addressing anyone specifically, speakers use expletives to release their frustrations and vent their emotions. Often they are reflexive reactions to something that has unexpectedly happened to the speaker. For instance, what would one say after having stubbed a toe? 
There are other categories of offensive language (compare Carpenter, 1988; Jay, 1992), but the types described above are the most common among native speakers.

\section{The Need to Understand English Taboo Language Use in North American Contexts}

Because the definitions above already provide some evidence of the types of linguistic functions obscenities serve for speakers, it can be reasonably argued that language students may find learning about obscene language practical. However, it is more important to understand its social and psychological significance to speakers, and it is in this vein that I would like to argue that adult language learners need classroom opportunities to discuss "dirty word etiquette" (Jay, 1992) in North American contexts. Before discussing any of the research that has been done in this area and its relative importance, I would like to offer an anecdote from my own professional experiences in support of the idea of discussing obscenities in classroom settings.

A female senior high school EFL student asked me about "bad words" in her weekly diary. She needed to understand what these words were used for, and why many American actors used them in movies. She inquired if it was acceptable for her to use them as well. My immediate kneejerk reaction was to discourage their use and to advise her not to discuss or think about taboo language. Although this may have been the most reactionary response for me to have had in talking about taboo words with my student, how uninformative it was, especially for a language learning student! So, via diary writing, we discussed what swear words were, and how problematic their use can be, even among native speakers. This student had legitimate questions about a part of English that exists but, unfortunately, is little spoken of in teaching contexts. Because language issues related to obscenities and their use are not widely studied, I was poorly informed and out on a "pedagogical limb" in following my own intuitions to deal with the situation the best way I knew how. Professionally, this is hardly a desirable situation for an instructor to be in.

In this case, I had to explain that some language in the movies is taboo language in many real-world situations, and it would be likely to reflect badly on speakers who would choose to use it. Yet it could be argued that this may not happen; the listener may well accept it. Surely complexities and contradictions like this have proved difficult for language learners to learn on their own outside a classroom. Empirical research is needed to tell us more, but it is probable that EFL/ESL speakers often misunderstand and misuse obscene language simply because they are left on their own to learn about its use. Perhaps classroom discussions will eventually help L2 speakers of English become better informed about the complexities and contradictions of cursing and what it signifies in North America. 
The above illustration is an incident taken from my own professional experiences in an EFL classroom. At that time, I was teaching in a context where all the students shared the same racial, cultural, and linguistic background. While there, I did not witness any aggressive verbal behavior among the students attending the school. However, discussions of taboo language such as racial slurs (i.e., chink, nigger, wop) or other derogatory remarks based on race, creed, or culture can be of relevance in the language class. Language instructors need to approach the sociolinguistic issues relevant to the use of words such as dyke, faggot, and fairy in their classes. First, though, they need to be armed with effective methods, materials, and appropriate training. We must begin to consider how best to approach taboo derogatory language in our classrooms.

I would also like to say emphatically that there are several ESL/EFL teachers who can give examples of their students being the targets of verbal bigotry and not understanding what it signifies. Surely these anecdotes should encourage surveys, interviews, and other ways of collecting these data so as to make a start at becoming better informed of the social and linguistic forces involved in the use of this type of language, and eventually, help language learners understand them too.

Thus far, I have found very little published on obscene language and its teaching implications for ESL/EFL students learning conversational English (Claire, 1980). This is quite surprising considering obscene language appears to be a linguistic universal (Foote \& Woodward, 1973), albeit taboo, and "fuck and shit are among the 75 most often spoken words [in American English]" (p. 265). On the other hand, there has been an increasing research interest in taboo language in terms of its sociological (Rieber, Wiedemann, \& D'Amato, 1979; Risch, 1987) and psychological (Bostrom, Baseheart, \& Rossiter, Jr., 1973; Kottke \& MacLeod, 1989) significance and in terms of its cultural linguistic development (Jay, 1981, 1992; Sagarin, 1968). In the section that follows, I would like to discuss some particular observations researchers have made about swearing in society, and at the same time suggest how speakers of English as a second language could benefit from this information if it were part of a language learning program.

\section{Nonlinguistic Variables Relevant to Cursing}

None of the aforementioned researchers specifically suggests that treatment of taboo language in classes could be beneficial for language learning students; however, many researchers, including those above, argue that there is much to learn from an examination of cursing practices. Obscene expressions can be a veritable gold mine for students of language in their efforts to study the important nonlinguistic variables that largely figure into people's speech behavior. 


\section{Discretion}

Speakers who use taboo language successfully (i.e., they do not seem to offend their listeners) are often attuned to the situation in which they are speaking. Jay (1992) and Foote and Woodward (1973) point out that those who swear successfully are usually mindful of the social restrictions placed on them in most situations, whereas those swearers who usually offend their audiences typically are not. For example, generally, society frowns on people swearing in front of children (Arango, 1989; Foote \& Woodward, 1973). Other examples of verbally restrictive social situations are speaking to new acquaintances, to one's parent(s), and to one's physician, even in the privacy of the examining office (Arango, 1989). Indiscriminate users of taboo language, by definition, would not feel restricted in similar circumstances. It has been suggested that careful speakers are probably sensitive to the status relationship they have with the above-mentioned types of individuals. Jay (1992) believes that because it is highly likely that such speakers would feel that their interlocutor was "above" them, the use of taboo language would be kept to a minimum. For the most part, however, the above-described situations are not only an issue of the speaker being of higher or lower status than the interlocutor, but familiarity and knowledge of the other person would also be influential factors governing the speaker's verbal behavior.

Moreover, successful swearers swear among friends where social status is not a primary worry, and friends normally accept such behavior (Foote \& Woodward, 1973). Jay (1992) argues that "good" swearers evaluate their listeners and do not swear if they realize that what they might say could be held against them. He states "sociolinguistics has clearly shown that children's or adults' use of language can characterize certain qualities about the user, for example, profession, intelligence ... or abstractness of thought" ( $p$. 87).

It is reasonable to assume that speakers who use taboo language would prompt similar value judgments among listeners as well. It may be best to swear among friends, where the speaker is relatively "safe" from negative listeners' judgments.

To summarize, research seems to indicate that discretion is important for successful swearing. In discussing extralinguistic aspects such as this, language learners may realize that there are rules involved in cursing that one cannot ignore. When speakers violate these rules, listeners tend to judge the speaker's character negatively. Therefore, ESL speakers should be advised that native English speakers tend to select their opportunities for swearing cautiously.

\section{Public versus Private Settings}

Setting also influences the appropriate use of obscenities (Jay, 1992; Kottke \& MacLeod, 1989; Risch, 1987). Studies confirm that English speakers feel taboo 
language belongs in a speaker's private domain rather than in a public setting. Jay (1992) refers to a study he conducted approximately 10 years ago with American college students who were native speakers of English. They reported campus locations where they would be likely to hear obscene words. Results showed that exclusive student places (i.e., men's dormitory, women's locker room, and the student pub) rated as the places where one was most likely to hear (and use) obscene language. Places that were more "official" and not part of the students' space were rated as the least likely places to hear obscene language (i.e., Admissions, Registrar's Office, and the Dean's Office). After analyzing these and other results, Jay concluded that American college freshmen who were native speakers of English did not consider obscene language appropriate for speakers who were not on home ground. In other words, these students objected to the use of obscene language if speakers were in official, publicly accessible places.

The above example illustrates that the environment affects the type of communication between speakers. It is important for English language learners to understand that the public or private nature of a conversational situation appears to determine whether the use of obscenity is acceptable. Information such as this may also help to clarify for L2 speakers why a native speaker may curse in one situation but not in another.

\section{The Gender Factor}

According to many of the findings reported in the literature on gender differences in obscene language use (Rieber et al., 1979; Risch, 1987; Selnow, 1985), if there is any part of the English language in which analysts could compare and contrast gender-specific verbal behavior, no part would be as telling as obscene language. Not all researchers agree on the ways males and females use, perceive, and are affected by taboo language, but several patterns are noted in cursing practices that could largely be termed as femaleoriented or male-oriented.

For instance, in studying female taboo talk, Risch (1987) wanted to determine whether women really are "more inhibited about the production of linguistic taboos and unlikely to admit to them" (p. 354). According to Risch, this is one of the more stereotypical perceptions in the United States of female speech behavior. Risch then collected lists of obscene expressions from 44 female sophomores and freshmen in which the women separated those expressions they used themselves from what they heard their female friends say. In the end, Risch claimed that women do not avoid taboo talk when referring to men across types of expression (i.e., references to body parts, body processes, etc.) or across classes (cohorts were a mixture of working, middle- and upper-class women). In all, the women listed 279 expressions, most of which they used themselves. Suggestive of the stereotypical speech behavior, however, Risch reported that the women 
preferred not to use obscenities in public or in mixed company. It appears that on one level, women do avoid taboo talk, but Risch's informal survey showed that this may have more to do with the opinion among women that obscene words are less appropriate in public environments than in private ones where taboo language seems to be comparatively freely used.

This contrasts with men's speech behavior. Studies show, for example, that men are less likely to use euphemisms publicly or privately (darn for damn; frig for fuck, Jay, 1992), will use obscenities to signal group membership and to discourage outsiders from joining the group (notice the verbal behavior of workers on construction sites), and will often swear to assert their social dominance over women (Selnow, 1985). Clearly, the gender of both speaker and listener will influence how, when, and where obscenities will be introduced into a conversation.

I have only briefly discussed the use of obscene language among male and female English speakers, but there is a clear difference in behavior between the sexes. I am not suggesting that male ESL speakers need to use obscene language. I am suggesting, however, that ESL/EFL speakers need to learn that swearing entails an understanding of the relevant variables involved in a speech situation. The gender of the interlocutors is definitely one variable that influences acceptable language use (including obscene language) among native English speakers.

\section{Conclusion}

Second language speakers may get a distorted idea of obscene language use due to the influence of movies, hit songs, and popular books where obscene language seems to flow unchecked. Nonetheless, students who are learning conversational English also need to learn what is acceptable or unacceptable in taboo language behavior. Having the opportunity to discuss it affords the learners the chance to understand the importance of the nonlinguistic practices that largely determine its use.

This article does not deal specifically with any practical concerns such as how to go about teaching taboo word etiquette. This is an important question that deserves empirical research. Moreover, some specific classroom-based research questions such as how female instructors might approach discussions of swearing with male students and vice versa may also lead to some useful conclusions. Other research topics could focus on how obscene language might best be approached. For example, on whose initiative, teachers' or students', should swearing be dealt with in class? Also, teacher training needs to be discussed if the study of obscene language is to be successfully planned and implemented. There is practical value in discussing obscene language in the language classroom and in teaching the nonlinguistic variables relevant to its use. ESL learners will hear and read obscenity around 
them, and may also be targets of it. Sociolinguistically they need to understand its system of etiquette and why it is so commonly used.

\section{The Author}

Robin-Eliece Mercury teaches oral communication and advanced writing in the English Language Institute at Kanda University of International Studies, Chiba, Japan. Her research interests include the pedagogical implications of obscene and derogatory language for ESL/EFL speakers and the types of knowledge ESL writers need to write successfully in university settings.

\section{References}

Arango, A. (1989). Dirty words: Psychoanalytic insights. Northvale, NJ: Jason Aronson.

Black, J.W., Stratton, C.S., Nichols, A.C., \& Chavez, M.A. (1985). The use of words in context: The vocabulary of college students. New York: Plenum.

Bostrom, R.N., Baseheart, J.R., \& Rossiter, C.M., Jr. (1973). The effects of three types of profane language in persuasive messages. Journal of Communication, 23, 461-475.

Carpenter, M. (1988). The link between language and consciousness: A practical philosophy. New York: University Press of America.

Claire, E. (1980). A foreign English student's guide to dangerous English. Rochelle Park, NJ: Eardley Publications.

de Klerk, V. (1991). Expletives: Men only? Communication Monographs, 58, 156-169.

Foote, R., \& Woodward, J. (1973). A preliminary investigation of obscene language. Journal of Psychology, 83, 263-275.

Hall, W.S., Nagy, W.E., \& Linn, R. (1984). Spoken words: Effects of situation and social group on oral word usage and frequency. Hillsdale, NJ: Erlbaum.

Jay, T.B. (1981). Comprehending dirty-word descriptions. Language and Speech, 24, 29-38.

Jay, T.B. (1992). Cursing in America. Philadelphia: John Benjamins.

Kottke, J.L., \& MacLeod, C.D. (1989). Use of profanity in the counseling interview. Psychological Reports, 65, 627-634.

Rieber, R.W., Wiedemann, C., \& D'Amato, J. (1979). Obscenity: Its frequency and context of usage as compared in males, nonfeminist females, and feminist females. Journal of Pscyholinguistic Research, 8, 201-223.

Risch, B. (1987). Women's derogatory terms for men: That's right, “dirty" words. Language in Society, 16, 353-358.

Sagarin, E. (1968). The anatomy of dirty words. New York: Lyle Stuart.

Selnow, G.W. (1985). Sex differences in uses and perceptions of profanity. Sex Roles, 12, 303-312. 